\title{
Deskripsi Pola Asuh Orang Tua Yang Menyebabkan Temper Tantrum Di Taman Kanak-Kanak Pembina Kota Pekanbaru
}

\author{
Pratiwi Gasril*, Yeni Yarnita \\ Keperawatan Universitas Muhammadiyah Riau \\ *Correspondence email: pratiwi@umri.ac.id
}

\begin{abstract}
Abstrak. Masa depan dan perkembangan anak akan sangat tergantung pada pengalaman yang mereka peroleh, termasuk pendidikan dan berbagai pola asuh orang tua yang terdiri dari pola asuh demokratis, permisif, dan otoriter. Tujuan dari penelitian untuk mengetahui gambaran pola asuh orang tua yang menyebabkan temper tantrum di Taman Kanak-kanak Pembina Kota Pekanbaru. Metode penelitian ini adalah studi deskriptif untuk mengetahui gambaran pola asuh orang tua yang menyebabkan temper tantrum pada usia pra sekolah dengan total sampling 109 responden. Hasil penelitian menunjukkan pola asuh orang tua demokrasi sebanyak 41 (37,6\%), pola asuh orang tua permisif sebanyak 63 (57,8\%), sedangkan pola asuh otoriter sebanyak 5 $(4,6 \%)$ dan hasil temper tantrum didapatkan temper tantrum berat sebanyak 2 orang $(1,8 \%)$, temper tantrum sedang sebanyak 33 orang $(30,3 \%)$, dan temper tantrum ringan sebanyak 74 roang $(67,9 \%)$. Hasil ini menunjukkan bahwa mayoritas pola asuh orang tua di Taman Kanak-kanak Pembina Kota Pekanbaru adalah permisif dan mayoritas kejadian temper tantrum ringan.
\end{abstract}

Kata kunci: Pola Asuh; Orang Tua; Temper Tantrum

\begin{abstract}
Kids' future and development will really depend on the experience they obtained, included education and various parenting patterns consisting of democratic parenting, permissive parenting, and authoritarian parenting. The purpose of this research is to find out the description of parenting pattern which causes temper tantrum at Pembina Kindegarten Pekanbaru City. The method of this research was descriptive study to find out the description of parenting pattern which causes temper tantrum in pre school age with total samples were 109 respondents. The research results show that democratic parenting is 41 (37,6\%), permissive parenting is 63 (57,8\%), while authoritarian parenting is 5 (4,6\%) and the result of temper tantrum obtains heavy temper tantrum in the amount of 2 children (1,8\%), medium temper tantrum in the amount of 33 people (30,3\%), and light temper tantrum in the amount of 74 people $(67,9 \%)$. These results show that the majority of parenting pattern at Pembina Kindegarten Pekanbaru City is permissive and the majority occurance is light temper tantrum.
\end{abstract}

Keywords: Parenting; Parents; Temper Tantrum

\section{PENDAHULUAN}

Pola asuh merupakan suatu sistem atau cara pendidikan dan pembinaan yang diberikan oleh orang tua kepada anaknya.Jadi, pengasuhan anak adalah kepemimpinan dan bimbingan kepada anak yang berkaitan dengan kepentingan hidup, perkembangan, seperti masalah perkembangan emosi yang biasanya terjadi pada anak, dengan salah satu gangguan diantaranya yaitu temper tantrum (Hasan, Maimunah. 2011). Temper tantrum dapat diartikan sebagai ledakan emosi atau luapan kemarahan yang dilakukan anak kecil. Tingkah laku ini biasanya mencapaititik terburuk sekitar usia 18 bulan hingga3 tahun, dan kadang masih dit emui padaanak usia 5 atau 6tahun (Ubaedy, A .N, 2009). Kesalahan yang sering dilakukan olehorang tua yaitu menerapkan pola asuhyang salah. Anak terlalu dimanjakan danselalu mendapatkan apa yang diinginkan, bisa temper tantrum ketika permintaannya ditolak. Anak yang terlalu dilindungi dandidominasi oleh orang tuanya, sekaliwaktu bisa bereaksi menentang dominasiorang tua dengan perilaku tantrum. Temper tantrum bila tidak ditangani sejakdini, maka tantrum yang buruk pada usia 3tahun akan terbawa sebagai masalahsampai masa dewasa. Sebuah faktapenelitian mengungkapkan bahwa anakyang pemarah (temper tantrum) seringtumbuh menjadi orang dewasa yang pemarah (temper tantrum) pula (Hasan, Maimunah. 2011).

Akibat yang ditimbulkan dari temper tantrum ini cukup berbahaya. misalnya anak yang melampiaskan kekesalannya dengan cara bergulingguling dilantai yang keras dapat menyebabkan anak menjadi cedera. Anak yang melampiaskan amarahnya dapat menyakiti dirinya sendiri, menyakiti orang lain atau merusak benda yang ada disekitarnya. (Zakiyah Nisaus. 2016).

Penelitian yang dilakukan di Chichago 50-80\% temper tantrum ini terjadi pada usia 2-3 tahun terjadi seminggu sekali, dan $20 \%$ terjadi hampir setiap hari, dan 3 atau lebih temper tantrum terjadi selama kurang lebih 15 menit (Tiffany, Cooke \& Gray, Lawrence. 2012). Penelitian lain di Northwestern Feinberg berdasarkan survei dari hampir 1.500 orang tua, studi ini menemukan bahwa $84 \%$ dari anak- anak usia 2-5 tahun meluapkan frustasinya dengan mengamuk dalam satu bulan terakhir, dan $8,6 \%$ diantaranya memiliki tantrum sehari-hari yang justru jika itu terjadi setiap hari merupakan tidak normal (Wakschlag, Lauren S et al, 2012). Berdasarkan permasalahn diatas maka peneliti tertarik untuk meneliti terkait Deskrisi Polah Asuh Orang Tua yang 
Menyebabkan Temper Tantrum di Taman kanak-kanak Pembina Kota Peknabaru.

\section{METODE}

Jenis penelitian deskriptif yang bertujuan untuk mengetahui gambaran sikap orang tua terhadap model dan tipe pola asuh pada anak usia prasekolah (Gasril, P., \& Hayana. 2019). Rancangan penelitian yang digunakan dalam penelitian ini adalah metode kuantitaf untuk mengetahui gambaran pola asuh orang tua yang menyebabkan temper tantrum di Taman Kanak-kanak Pembina Kota Pekanbaru.

Populasi dalam penelitian ini adalah orang tua dari anak yang bersekolah di taman kanak-kanak se pekanbaru. Teknik sampling yang digunakan menggunakan teknik cluster sampling. Instrumen yang digunakan berupa kuisioner. Sampel dalam penelitian ini adalah orang tua dari anak yang bersekolah di Taman Kanak-kanak Pembina Kota Pekanbaru sebanyak 109 orang.

\section{HASIL DAN PEMBAHASAN}

Tabel 1. Distribusi Pola Asuh Orang Tua di taman kanakkanak pembina kota Pekanbaru Tahun $2020(\mathrm{n}=109)$

\begin{tabular}{lcc}
\hline Pola Asuh & Frekuensi & Persentase \\
\hline - Demokratif & 41 & 37,6 \\
- Permisif & 63 & 57,8 \\
- Otoriter & 5 & 4,6 \\
\hline
\end{tabular}

Berdasarkan hasil penelitian didapatkan pola asuh orang tua demokrasi sebanyak $41(37,6 \%)$, pola asuh orang tua permisif sebanyak $63(57,8 \%)$, sedangkan pola asuh otoriter sebanyak $5(4,6 \%)$.

Berdasarkan hasil penelitian didapatkan hasil bahwa sebanyak 63 orang tua $(57,8 \%)$ memiliki pola asuh permesif, 41 orang tua memiliki pola asuh demokratif $(37,6 \%)$, dan 5 orang tua memiliki pola asuh otoriter $(4,6 \%)$. Hasil penelitian ini tidak sejalan denga penelitian yang dilakukan oleh Yulianti, Pratama dan Mastuty (2019) didapatkan hasil bahwa pola asuh orang tua didapatkan pola asuh demokratif sebanyak demokratis 24 anak $(68,6 \%)$, dan jumlah pola asuh orang tua otoriter sebanyak 11 anak $(31,4 \%)$ tetapi tidak ditemukan anak yang mengalami pola asuh permisif.

Hasil penelitian ini tidak sejalan dengan Kirana (2013) yang melakukan penelitian tentang pola asuh orang tua pada anak pra sekolah di RW 01 Bawen, hasil penelitian tersebut menunjukkan terdapat tiga pola asuh yaitu Demokratis $41 \%$, Permisif $14 \%$, namun lebih mengarah ke otoriter dengan persentase $45 \%$. Pada penelitian ini terdapat pola asuh permesif lebih tinggi dari pada pola asuh demokratis dan terdapat sebagian kecil pola asuh otoriter. Hasil penelitian lain yang dilakukan oleh Alini dan Jannah (2019) orang tua yang menerapkan pola asuh demokratis sebagian besar dengan kategori sedang yaitu 21 orang tua $(70,0 \%)$, kemudian hampir setengah dari orang tua yang menerapkan pola asuh otoriter kategori sedang yaitu 14 orang $(46,7 \%)$, sedangkan untuk pola asuh permisif setengah dari orang tua menerapkan kategori rendah yaitu 15 orang $(50,0 \%)$.

Hal ini dikarenakan usia orang tua yang rata-rata telah mencapai 35 tahun, sehingga lebih mempertahankan konsep tradisional yang didapat dari turunmenurun orang tua sebelumnya. Prinsip ini menyebabkan pola asuh permesif lebih dominan diterapkan kepada anak, akan tetapi juga terdapat orang tua yang memahami pola asuh demokratis lebih baik digunakan untuk anaknya dikarenakan orang tua sudah mendapatkan pendidikan yang cukup dan telah membandingkan antara pola asuh demokratis dan pola asuh otoriter yang didapatnya semasa kecil.

Pada penelitian ini juga terdapat pola asuh demokratif, hal ini dikarenakan oleh faktor ekonomi dimana orang tua sibuk bekerja, dan terkadang lupa memberikan perhatian khusus kepada anaknya, dan juga bisa disebabkan oleh terlalu memanjakan anaknya. Semakin banyak faktor yang dapat berhubungan dengan perkembangan dan pembentukan karakter anak, maka diperlukan pendekatan khusus dari orang tua dengan anak dalam membentuk perilaku yang positif, sikap yang positif akan mempengaruhi besar terbentuknya karakter anak yang baik dan sesuai dengan norma yang telah ada, dan menjauhkan dari hal-hal yang bersifat negatif dan hal-hal yang membahayakan bagi anak itu sendiri (Yulianti, Pratama \& Mastuty, 2019).

Tabel 2. Distribusi Temper Tantrum di taman kanak-kanak pembina kota Pekanbaru Tahun $2020(n=109)$

\begin{tabular}{lcc}
\hline Temper Tantrum & Frekuensi & Persentase \\
\hline - Berat & 2 & 1,8 \\
- Sedang & 33 & 30,3 \\
- Ringan & 74 & 67,9 \\
\hline
\end{tabular}

Berdasarkan hasil penelitian didapatkan temper tantrum berat sebanyak $2(1,8 \%)$, temper tantrum sedang sebanyak $33(30,3 \%)$, sedangkan temper tantrum ringan sebanyak $74(67,9 \%)$.

Berdasarkan hasil penelitian didapatkan hasil bahwa sebanyak 74 orang tua $(67,9 \%)$ memiliki tipe temper tantrum ringan. 33 orang tua $(30,3 \%)$ memiliki tipe temper tantrum sedang dan 2 orang tua $(1,8 \%)$ memiliki tipe temper tantrum berat. Hasil penelitian ini tidak sejalan dengan penelitian yang di lakukan oleh Lusiana (2015) diketahui sebagian besar responden yaitu sebanyak 19 responden (42,2\%) menunjukkan temper tantrum yang tinggi. dengan temper tantrum rendah yaitu 11 responden $(52,4)$.

\section{SIMPULAN}

Hasil dari penelitian ini didapatkan pola asuh orang tua demokrasi sebanyak $41(37,6 \%)$, pola asuh orang tua permisif sebanyak $63(57,8 \%)$, sedangkan pola asuh otoriter sebanyak $5(4,6 \%)$ dan hasil temper 
tantrum didapatkan temper tantrum berat sebanyak 2 orang $(1,8 \%)$, temper tantrum sedang sebanyak 33 orang $(30,3 \%)$, dan temper tantrum ringan sebanyak 74 roang $(67,9 \%)$

\section{DAFTAR PUSTAKA}

Alini, \& Jannah, W. (2019). HubunganPolaAsuh Orang Tuadengan Kejadian Temper Tantrum PadaAnakUsiaPrasekolah di Kelompok Bermain Permata. 3 Nomor 2(23), 1 - 10. https://journal.universitaspahlawan.ac.id/index.ph p/ners/article/viewFile/395/330

Gasril, P., \& Hayana. (2019). Deskripsi Pola Asuh Orang Tua Pada Anak Usia Prasekolah Ditaman Kanak-Kanak Pembina Se Kota Pekanbaru. Photon: Jurnal Sain Dan Kesehatan, 10(1), 13-16. https://doi.org/10.37859/jp.v10i1.1473

Hasan, Maimunah. (2011). Pendidikan Anak Usia Dini. Yogyakarta: Diva Press.

Kirana (2013). Hubungan Pola Asuh Orang Tua dengan Temper Tantrum Pada anak Pra Sekolah. Skripsi https://lib.unnes.ac.id/

Lusiana. (2015). Perbedaan risiko temper tantrum anak usia prasekolahantara ibu bekerja dan tidak bekerja di Roudlotul Atfalman 2 Kelurahan Gebang Kecamatan Patrang Kabupaten Jember. Http://Repository.Unej.Ac.Id/Handle/123456789/ $\underline{65916 .}$

Tiffany, Cooke \& Gray, Lawrence. 2012. Temper Tantrums and Management. Pediatrics University of Chicago.

Ubaedy, A .N. (2009). Cerdas mengasuh anak. Jakarta Selatan: KinzaBooks

Wakschlag, Lauren S., Choi, Seung W., Carter, Alice S. 2012. Defining the developmental parameters of temper loss in early childhood: implication for developmental psychopathology. The Journal of Child Psychology and Psychiatry (Vol. 53, No.11, November 2012).

Yulianti, Pratama dan Mastuty (2019). Analisis Hubungan Pola Asuh Orang Tua Dengan Tingkat Kemandirian Personal Hygiene Pada Anak Usia Pra Sekolah Di Dusun Celegeh Desa Barebali Lombok Tengah Tahun 2019. Jurnal surya muda, Vol. 1 no. 2. DOI: https://doi.org/10.38102/jsm.v1i2.40

Zakiyah Nisaus. 2016. Hubungan Pola Asuh Orang Tua Dengan Kejadian Temper Tantrum Pada Anak Usia Toddler Di Dukuh Pelem Kelurahan Baturetno Banguntapan Bantul. Jurnal Terpadu Ilmu Kesehatan, Volume 6, No 1,Mei 2016, hlm01-117. 